\section{HSE}

Historia Social y de la Educación

Social and Education History
Hipatia Press

www.hipatiapress.com

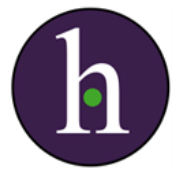

Instructions for authors, subscriptions and further details:

$\underline{\text { http://hse.hipatiapress.com }}$

Seeking new paradigms in aboriginal education research: methodological opportunities, challenges and aspirations

Marnee Shay ${ }^{1}$

1) Queensland University of Technology (Australia)

Date of publication: October 23rd, 2016

Edition period: October 2016 - February 2016

To cite this article: Shay, M. (2016). Seeking new paradigms in aboriginal education research: methodological opportunities, challenges and aspirations. Social and Education History 5(3), 273-296. doi:10.17583/hse.2016.2299

To link this article: http://dx.doi.org/10.17583/hse.2016.2299

PLEASE SCROLL DOWN FOR ARTICLE

The terms and conditions of use are related to the Open Journal System and to Creative Commons Attribution License (CC-BY). 


\title{
Seeking New Paradigms in Aboriginal Education Research: Methodological Opportunities, Challenges and Aspirations
}

\author{
Marnee Shay \\ Queensland University of Technology \\ (Australia)
}

\section{Abstract}

It is only relatively recently that Aboriginal peoples in Australia are represented in the academe, creating knowledges that speak for, and not of us. Internationally renowned Maori scholar, Professor Linda Tuhiwai Smith, was groundbreaking in her use of critical discourses needed for indigenous peoples globally to reclaim our knowledges and experiences through research. The emergence of Aboriginal and Torres Strait Islander scholars in Australia presents hope and opportunities for our communities to utilise the possibilities that ethical, Indigenous-driven research can have in interrogating complex and ongoing issues created by colonialism. Research that theorises Aboriginal epistemic and ontological research paradigms in Australia are still developing. Moreover, discipline-specific theoretical frameworks and methodologies are still emerging. This paper outlines my experience as an Aboriginal researcher in utilising Indigenist theoretical principles and methodological approaches. Using autobiographical reflections from my doctoral research, I present a range of practical implications that arise when the 'researched' shifts to the researcher in Western-dominated spaces such as schools. I will critically analyse the question, are Aboriginal researchers able to conduct research that is motivated by our agendas, ideas and aspirations in a discipline that perpetuates imperialism, racism and exclusion?

Keywords: indigenous, aboriginal, education research, access, gatekeeping 


\title{
La Búsqueda de Nuevos Paradigmas en la Investigación de la Educación
} Aborigen: Oportunidades Metodológicas, Desafíos y Aspiraciones

\author{
Marnee Shay \\ Queensland University of Technology \\ (Australia)
}

\section{Resumen}

Hace relativamente poco tiempo que los pueblos aborígenes de Australia han empezado a estar representados en el mundo académico, creando conocimientos que hablan por y no sobre nosotros. La profesora Linda Tuhiwai Smith, investigadora maorí internacionalmente reconocida, fue pionera en su uso de los discursos críticos necesarios para los pueblos indígenas en todo el mundo para reclamar nuestros conocimientos y experiencias a través de la investigación. La aparición de académicos aborígenes e isleños de Torres Strait en Australia aporta esperanza y oportunidades a nuestras comunidades para aprovechar las posibilidades que la investigación ética e impulsada por las propias personas indígenas puede aportar en el cuestionamiento de aspectos complejos y persistentes creados por el colonialismo. La investigación que teoriza los paradigmas epistemológicos y ontológicos de la investigación aborigen en Australia aún se están desarrollando. Además, los marcos teóricos y las metodologías específicas en la disciplina aún están emergiendo. Este artículo describe mi experiencia como investigadora aborigen en la utilización de los principios teóricos indigenistas y los enfoques metodológicos. A través del uso de reflexiones autobiográficas extraídas de mi investigación doctoral, presento una serie de implicaciones prácticas que surgen cuando el "investigado" pasa a ser el investigador en espacios dominados por occidentales como las escuelas. Analizaré críticamente la cuestión: los investigadores e investigadoras aborígenes, ¿somos capaces de llevar a cabo investigaciones motivadas por nuestros criterios, ideas y aspiraciones en una disciplina que perpetúa el imperialismo, el racismo y la exclusión?

Palabras clave: indígena, aborigen, investigación educativa, acceso, gatekeeping 
I am an early career Aboriginal researcher. My people are from Wagiman country in Daly River, Northern Territory through my Mother and Grandmother. Professionally, I have a youth work and teaching background. My teaching experience was predominantly in an education setting called 'Flexi Schools'. Flexi schools provide young people who have been disenfranchised from education the opportunity to reengage with learning (Shay, 2015). My research work has predominantly been in the Flexi Schooling context, with a particular focus on Indigenous engagement and experiences in this educational setting.

In this paper, I will use some of my autobiographical research reflections from my doctoral research, which explored the roles and experiences of Indigenous staff working in Flexi Schools. I took the position early on in conceptualising my project that I would choose theoretical and methodological approaches that connected to who I am and how I have experienced education as an Aboriginal person. I utilised Indigenous Standpoint Theory (Rigney, 2006) and Critical Race Theory (LadsonBillings, 1998) as the theoretical framework and utilised yarning as a methodology (Bessarab \& Ng'andu, 2010). Although it is beyond the scope of this paper to utilise my reflections of using yarning methodology, use of Indigenous methodologies such as yarning within educational research reveals the pervasiveness of Western paradigms even within 'Indigenous research'.

Due to the emerging nature of Indigenist research in Australia, it became clear at various times throughout undertaking this project that my reflections from doing this research may be just as much of a contribution as the data from the research itself. Bold (2012) discerns that some of the most insightful research is that which captures the whole story. In my doctoral study, I recognised the need to think and write as much about the process as the data itself. Aboriginal and Torres Strait Islander peoples are still establishing our own corpus of work that theorises knowledge production in a way that embodies our ways of knowing, being and doing (Martin, 2003). It is my aim to make a small contribution to the ongoing development of Indigenous scholarship.

In this paper, I will first outline my reflections about negotiating the space as an Aboriginal researcher in institutionalised education settings. I will discuss and provide an in-depth analysis of the issues that arise 
specifically for Indigenous researchers' access to research participants in institutionalised education settings. Furthermore, I will also raise some questions about existing Indigenous research ethical guidelines and the issues that they do not address for Indigenous researchers. The second topic to emerge from my reflection was gatekeeping in Indigenous education research and the specific implications for Indigenous researchers. I will use some examples of issues that have emerged from the broader gatekeeping literature to consider the explicit issues that potentially arise for Indigenous researchers who want to undertake Indigenous research in education settings.

\section{Access, Ethics and Indigenist Research}

Owing to historical practices in research that dehumanised, objectified and excluded Indigenous peoples from knowledge produced about us (Rigney, 2001), there is now a body of literature that emphasises ethical practices in conducting research that involves Indigenous peoples and communities. The increasing presence of Indigenous researchers presents opportunity for ongoing debate about conducting research with an Indigenous focus, from Indigenous perspectives in addition to non-Indigenous perspectives. Although there is a body of literature that speaks to Indigenous researchers (Foley, 2003; Martin, 2003; Moreton-Robinson, 2003; Nakata, 2007; Rigney, 2006), much of the literature speaks to and for non-Indigenous researchers undertaking Indigenous research.

There are two key documents that a researcher (Indigenous or nonIndigenous) must be familiar with if they are wanting to conduct research in Indigenous communities. The first ethical research guidelines for Indigenous research was developed by the National Health \& Medical Research Council (NHMRC) and published in 1991. This earlier version has now been replaced with 'Values and Ethics: Guidelines for Ethical Conduct in Aboriginal and Torres Strait Islander Health Research', published in 2003 (National Health \& Medical Research Council, 2003). The guidelines focus on research in Indigenous health contexts although they are often referred to by many researchers across disciplines. The NHMRC guidelines outline 
values and ethics needed for conduct of ethical Indigenous research including principles of reciprocity, respect, equality, responsibility, survival and protection and spirit and integrity (National Health \& Medical Research Council, 2003). The NHMRC emphasise relationships to counter the poor consultation that has occurred in the past with Indigenous participants of research. Moreover, the establishment of trust is also proposed as being central to shifting the power relationships that were the source of poor research relations between non-Indigenous researchers and Indigenous peoples.

The second key ethical framework was developed by the Australian Institute of Aboriginal and Torres Strait Islander Studies (AIATSIS). First published in 2002 and then updated and republished in 2012, the 'Guidelines of Ethical Research in Australian Indigenous Studies' is less health specific and provides researchers another set of recommendations for ethical research involving Indigenous peoples (Australian Institute of Aboriginal and Torres Strait Islander Studies, 2012). In the AIATSIS guidelines, fourteen principles are set out to frame how researchers should conduct ethical research with Indigenous peoples. The principles address issues such as rights and recognition of Indigenous peoples, consultation and informed consent, beneficence and outcomes serving the interests and needs of Indigenous peoples. AIATSIS cite human rights and self determination as the underlying principles for the development of these guidelines.

The guidelines and other literature that I engaged with when considering that my study will be Indigenous focused and only working with Indigenous participants, are written to a broad and what is assumed, mostly nonIndigenous audience. To me this places Aboriginal and Torres Strait Islander researchers in an ambiguous position. It can't be assumed that because we are Aboriginal or Torres Strait Islander that we will undertake research ethically. Notwithstanding, we are also circuitously bound into the very existence of the guidelines. Although we (Indigenous peoples) are now present and actively contributing to scholarship about us, the development of a body of literature that reflects the complexity of how we are currently positioned in the research space is still emerging.

I engaged with the AIATSIS and NHMRC guidelines when conceptualising this research and writing the ethics application for my project. The first gap I identified was that although I am Aboriginal and 
undertaking research which only includes Indigenous participants, this research was to take place in the specific context of schools. The institutionalised nature of education systems (both schools and universities) presents considerable issues in the practicalities of undertaking what I would name as Indigenist research in institutionalised contexts. Below is a reflection from my experience in navigating access to school sites for this research.

\section{Reflection}

Once I defined what flexi schools I want to work with in my study and why, I set about considering how I would work with participants. I had good existing relationships with some school communities because of my experience of teaching in multiple flexi schools. However, because I am now a researcher, how I approach Aboriginal and Torres Strait Islander staff to participate will need to be how the university dictates is an appropriate method for contacting potential participants. This was indeed a conundrum. My experience and knowledge as an Aboriginal person tells me very distinctively to ensure that I have consulted with mob on the ground, first and foremost. This did take place informally (well before I enrolled in a $P h D)$, which is how I knew that this research was something that Indigenous staff would see as valuable. However, I am now formally the researcher so bypassing formal hierarchies within the schools that I want to include in my study was not only a bad idea, it would be considered an unethical process.

Once I identified the schools, they were contacted via email as promised in my ethics approval. The way of negotiating forward differed because some flexi schools belonged to a network of more than one school and others were stand-alone independent schools where I had contacted the principal directly. I was only invited to meet face-to-face with one person who was in a high position systemically to make a decision about whether or not to grant access to Indigenous staff at their school sites. He was a white male manager with whom I had an existing relationship. We engaged in good critical conversation about what participation would involve, what my research questions were and discussion about my research design. This particular leader was emphatic of his support of the research. He made the 
decision in this meeting that he felt my research was so important that he would fund the cost of having Indigenous staff from multiple sites out from their schools for a day.

I drove away from that meeting feeling relieved. This man who held all of the authority to say yes or no to accessing Indigenous staff at multiple school sites (some of which have very high Indigenous enrolments) had not only said yes to supporting me to access participants, but also expressed that he valued the research I was about to embark on. In the car on the way home, I stopped to think - what if he had said no? What if he didn't know me, would that have impacted on his decision? If I was white, would he have still supported the very same study? That is great that he supports it, what if the school authorities below him don't support it?

As it turned out, the issues underlying some of the questions I asked myself on that drive home would continue to emerge as I contacted other schools that were stand-alone sites to recruit Indigenous participants. I had many schools who completely ignored my recruitment email. The ignoring of my email could only lead me to one of three conclusions. The first, that the principal discussed it with their Indigenous staff and they said no they weren't interested and the principal decided not to reply to communicate this. The second, that the principal didn't like what they read about the project and decided that they didn't want their Indigenous staff to be involved in such a study. The third, that the principal is too busy or saturated with research requests that they decided to ignore the email all together.

There were other replies. One was that there were not any Indigenous staff employed at the school currently. A legitimate reason not to be able to participate, I thought! The other was from a principal stating that they are not a flexi school. I took the time to reply and explain how I defined flexi schools (non-deficit) and that their school did offer education (with high Indigenous enrolments) that fits this definition but I did not get a reply to this email.

The principals and school leaders who worked directly under the man in the leadership position who had supported the study initially had mixed responses to my follow up communication. The majority were supportive in principle although the practical reality of having Indigenous staff away from their roles in schools surfaced as a very real barrier. Then there were others 
who were very proactive in passing information along and providing Indigenous staff the opportunity to participate in work time if they chose to.

\section{Institutionalised Education Settings and Indigenist Research}

The institutionalised nature of education presented very real implications and lessons for me as an Aboriginal researcher that I see as presently missing from Indigenous research literature. Indigenist research theories and methodologies are becoming a strong presence in the literature, although the translation of the theoretical principles to the practical reality of undertaking education research is not well documented. Ethical conduct of Indigenous research is emphasised through the guidelines discussed above by Australian Institute of Aboriginal and Torres Strait Islander Studies (2012) and the National Health \& Medical Research Council (2003). However, how are Aboriginal researchers able to conduct research that is motivated by our agendas, ideas and aspirations in a discipline and context that perpetuates imperialism, racism and exclusion?

My experience in navigating access to Indigenous participants in school sites guided me towards thinking about how Indigenous researchers negotiate institutionalised, western dominated spaces to undertake research that is proclaimed as being ethical in Indigenous research guidelines. Principles such as self-determination and consultation are nearing towards impossible when Indigenous researchers seek to undertake Indigenous research in education contexts and I would propose other institutionalised settings also. The regulating and governing of research agendas in education lays squarely with either bureaucrats in a large system or education leaders are in charge of individual school sites.

Schools have long been recognised in the literature as an institutionalised performative that functions far beyond that task of educating children (Berg, 2007; Jakobi, 2011; Ramirez \& Boli, 1987). Institutional theory "highlights cultural influences on decision making and formal structures" (Barley \& Tolbert, 1997, p. 93). Ramirez and Boli (1987) argue that the institutionalisation of education has resulted in the creation of mass schooling in almost every western European country. Moreover, Ramirez 
and Boli (1987) further discern that the purpose of mass schooling is "part of an endeavour to construct a unified national polity" (p. 3). Schools thus function as a mechanism to serve broader societal interests. Berg (2007) concludes that schools as institutions are then "the agency responsible for the reproduction of society, that is for instilling, e.g. social norms, cultural traditions, and the transmission of the knowledge and skills necessary to the individual and society" (p. 581). Analysis of the types of institutions and critique of how they discursively constitute the agendas of nation states are critical in education discourse.

The function of institutionalising schools is closely connected to the need for nation states to uphold national identities and values (Ramirez \& Boli, 1987). Nation states achieve their purpose of conformation through control, regulation and expected compliance by schools in upholding unity in 'shared' values and goals. This emphasis on national development in each individual school has resulted devaluing of the continuation of indigenous knowledges and principles, as well as diminishing of local and minority needs (Ramirez \& Boli, 1987).

Institutions such as schools reinforce dominant social norms, expectations and agendas. In an Australian context, the colonial project that originally saw Indigenous peoples rendered as sub-human through the declaration of 'terra nullius', continues to permeate through institutionalised, racial discourse in all institutions, including schools. Schools as institutions in Australia continue to uphold a national identity that ignores the brutality and dispossession of Indigenous peoples and constructs white Australians as the social norm. Some overt support of this statement is reflected in the data that demonstrates the under-representation of Indigenous principals, teachers, support staff or politicians who influence education policy (Australian Government, 2012, 2014; Lampert \& Burnett, 2012). Further evidence is in the western curriculum that has excluded teaching about the massacres and dispossession of Indigenous peoples in place of the 'Captain Cook' narrative of discovery of a great foreign land; the refusal to include teaching the many Aboriginal and Torres Strait Islander languages; the ongoing practices of deficit and stereotypical re-presentations by teachers of who Indigenous people are and the resistance to embedding of Indigenous perspectives and knowledges in the national curriculum (Ma Rhea, 2013; Phillips \& Lampert, 2012). 
Understanding how schools as institutions operate to serve the interests of the dominant culture is a critical aspect of the discussion about Indigenous researchers access to undertake Indigenous research in schools. For an Indigenous researcher to reach the position of being the researcher, one must: successfully navigate an institution as a child that is not functioning to support their interests or needs; access a different but similar institution to undertake tertiary studies (in an environment where we are even more critically under-represented); return to undertake research training where the likelihood of having someone teach you who is of the same cultural background is very low; and finally, construct a research project that affirms who you are culturally but also meets the needs of and is accepted by the institution. Once this is achieved, an Indigenous researcher who wants to undertake education research will then need to navigate the school institution again; this time, from the position of a researcher.

Shifting from the object of research to the researcher means a reconstruction of how we are socially positioned as Aboriginal peoples. In navigating schools as institutions, this means that Indigenous researchers will inevitably be met with similar issues as we were met with as students of the same institutions including being constructed as 'other'; inferior; subhuman and so forth. When Indigenous peoples become the researcher, it is not just the straight forward issues that arise with accessing school sites to undertake their research; there is a set of historical and social assumptions that we are structurally and individually met.

The notion of self determination, espoused by the two key ethical Indigenous research documents outlined earlier (AIATSIS and NHMRC) is therefore very unlikely to be possible in Indigenous education research. To consult with Indigenous people, create shared visions and collaborate with Indigenous peoples within education institutions is only possible if access is granted by the 'gatekeeper'. In school institutions, the gatekeeper will be the school leader (principal, lead teacher, head of campus) or higher up the bureaucracy within the system. In the Australian context, this person is unlikely to be an Aboriginal or Torres Strait Islander person, given how critically under-represented we are in educator and leadership roles (Australian Government, 2014). The role of gatekeeping within institutions 
will now be analysed. Such analysis is critical in bringing forward new ideas about ethics and new conversations for Indigenous researchers who want to undertake Indigenist research in education contexts.

\section{Gatekeeping and Indigenist Research in Education: Ethics or 'Protectionism'?}

Predictably, there is a body of literature on the concept of gatekeeping in research (Heath, Charles, Crow, \& Wiles, 2007; Murgatroyd, Karimi, Robinson, \& Rada, 2015; Sanghera \& Thapar-Björkert, 2008; Shoemaker \& Vos, 2009; Wanat, 2008). Gatekeeping of research has been written about across disciplines, with Wanat (2008) proposing that gaining access in a research context is unique to each study. The impartiality of the gatekeeping role has been noted in the literature for some time as being problematic (Shoemaker \& Vos, 2009). Murgatroyd et al. (2015) examined the role of gatekeeping in health research, identifying that gaps between practice and research will persevere with the "misuse of gatekeeping powers" (p. S163). Murgatroyd et al. (2015) further distinguish the misuse of gatekeeping roles as "Nimbyism"; a term which was used originally in the 1980's to describe residents who were in opposition of new developments in their neighbourhoods. Although residents agreed with the social outcomes that these developments might produce, they didn't want them in their neighbourhood. Thus, the term 'not in my backyard' was born. There are several layers to Nimbyism that impact on researchers that are defined by Murgatroyd et al. "Conditions of entry, defining the problem of study, access to data and respondents, funding and scope of analysis" (Murgatroyd et al., 2015, p. S163) are all influenced by Gatekeepers.

Heath et al. (2007) propose that gatekeepers can play an important ethical role, particularly for research involving children and other participants who are perceived as vulnerable. However, ethics in qualitative research include informed consent, which can only take place if potential participants have the opportunity to engage fully with the would-be researchers. Heath et al. (2007) further explain that in an institutionalised setting, most are "agestructured" (p. 405) consequently positing adults as authorities and decisionmakers. As institutionalised settings have a set of enforced conditions well 
outside the influence of potential participants or gatekeepers, Heath et al then question the ability to authentically gain informed consent if the participation is only decided upon by a gatekeeper. The issue that arises from this set of conditions is then about agency and decision making on behalf of potential participants. Status inequality, subordination and organisational constraints are all genuine issues that emerge when considering the ethics of gatekeeping and informed consent.

Sanghera and Thapar-Björkert (2008) conclude that the underlying dynamic that influences whether access is granted by a gatekeeper is the researcher-gatekeeper relationship, further outlining that "it is a relationship that is fraught with inconsistencies and instabilities" (p.544). Sanghera and Thapar-Björkert (2008) wrote of their research context, which was an inquiry of social capital in a complex, low socioeconomic community called Bradford in the United Kingdom. Ethnic diversity in the community is high and the researcher was wanting to research participants who may not have been of the same 'class' position, but likely of the same race categorisation. It was the position of the researcher that led to some rich insights about positionality (race, class, gender) and how it governs professional and social relationships. As the researcher was "British-born with Indian skin" (p.554), the researcher found himself fielding questions not only about his research, but about why he had brown skin and of Indian appearance but had a British accent. Accordingly, how gatekeepers constructed him as a person impacted on his relationships and interactions with him.

The unpredictability of how relationships are operationalised in gatekeeping/researcher interactions matters because it impacts on how knowledge is produced (Wanat, 2008). Wanat (2008) argues that high level gatekeepers tend to steer away from sensitive topics. Mediating access to participants is not only based on perceived benefits, it also based on perceived threats (organisational and individual). Wanat (2008) also raises the issue of translation of higher cooperation to lower level cooperation. Providing access through a systemic gatekeeper at a higher level does not always mean that the lower level will provide access to potential participants, particularly if the access isn't supported with resources or general support of the study. Wanat (2008) concluded that personal 
connections, at higher or lower levels in school research has the most impact on how researchers navigate gatekeeping.

Gatekeeping generally in Aboriginal and Torres Strait Islander communities is also not an unfamiliar concept. The Merriam Webster dictionary defines gatekeeping two ways. The first is defined as "a person who guards a gate". The second is defined as "a person who controls access" (Merriam-Webster, 2016). The metaphorical gate that can be applied when thinking about the concept of gatekeeping in Indigenous communities is the entry way to social, health, education, and economic equality that Indigenous peoples have fought for since invasion of Australia. Although who controls access to this equality is greater than just one person, the system that has blocked equality from being met over the past couple of centuries continues to prevent access to this equality. The person or persons who control the access are simply actors that are serving the interests of the very system that blocks access to equality, time and time again.

Historical policies such as protectionism are implicated in the gatekeeping that continues to pervade in many Indigenous communities around Australia. The protectionism rule that governed Indigenous peoples particularly from the early nineteenth century created a discourse that Indigenous peoples require protection or saving from ourselves and from others (Moran, 2005). What was initially a Government policy that was presented as preserving and safeguarding Indigenous peoples saw many thousands of Indigenous peoples removed from their traditional homelands and consequently separated from their families, language, and culture. Although the policy names (merging, absorption, assimilation) and ideology varied slightly over the subsequent decades up until the latter half of the nineteenth century, one consistent factor remained: the control and ruling of Indigenous lives by white missionaries, government officials and managers (Moran, 2005).

As outlined above, different scholars have written of their experiences of gatekeeping in varying discipline and context specific circumstances. All of this literature assists in critiquing how research and therefore knowledge production is mediated and for whose interest is the knowledge being created. In the context of Indigenous Australia, there are several key points in situ that I believe need to be raised for future Indigenous (and perhaps 
non-Indigenous researchers) in relation to gatekeeping Indigenist education research, by Indigenous researchers.

At the beginning of this section on gatekeeping, I cited the term Nimbyism, which referred to gatekeepers who might in essence support the social or moral value of the research, but 'not in their backyard' (Murgatroyd et al., 2015). In reference to Indigenist research conducted by Indigenous researchers, I believe this will continue to be an ongoing issue for some time to come. In the research context, we continue to see research that focuses on Indigenous learners as the problem; an abundance of research undertaken by non-Indigenous researchers researching the problematic 'other' and an ongoing obsession with comparative, scientific measurements of educational outcomes (Harrison, 2007).

Although many schools are now providing practices that are considered culturally inclusive, there remains a deficit discourse saturated with concepts of otherness that ensures Indigenous students are kept well below their nonIndigenous peers. The broader education policy space has seen some positive changes: the introduction of embedding Indigenous knowledges as a cross curriculum priority area (ACARA, 2015); the introduction of teacher standards that require teachers to know about Indigenous histories and have strategies to teach and support Indigenous students (AITSL, 2013) and increasing universities ensuring mandatory Indigenous education units within pre-service teacher education programs (Hart, Whatman, McLaughlin, \& Sharma-Brymer, 2012; Ma Rhea, 2013). Yet, these broader policy changes may not necessarily mean that Indigenist researchers who wish to undertake research in an education space on one of these topics will be granted access by a gatekeeper.

The school gatekeeper may be increasing their work in the area of Indigenous education. However, a study that might include critical observations or in depth analysis by the cultural 'other' may be perceived as useful, but 'not in their backyard'. In the context of this study, although I have no evidence beyond the correspondence between myself and gatekeepers, I believe this was an issue in some cases. I do not doubt the considerable limitations on school resources. However, a common issue that emerged at data collection at all sites was the ability to gain access to 
participants. Gatekeepers were quick to assure me how important the topic of Indigenous staff was, particularly due to the high Indigenous numbers of students and staff. Conversely, some gatekeepers only allowed access after ongoing persistence on my part or compromising on how I had planned to work with participants in collecting data to utilise the little time that was made available.

Murgatroyd et al. (2015) discussed the multiple aspects of control that gatekeepers have in research: "conditions of entry, defining the problem of the study, access to data and respondents, funding and scope of analysis" ( $p$. S165). The historically situated discourse in Indigenous education has always been socially and ideologically stipulated by white Australia. The conditions of entry in accessing education up until the latter end of the nineteenth century were clearly governed by racialised ideas that Indigenous peoples were intellectually inferior or "uneducable" (Price, 2012, p. 2). The conditions of entry into the space of knowledge production has not been different, with an emergence of Indigenous scholars writing of the challenges and their experiences of undertaking research within Western knowledge systems (Martin, 2012; Moreton-Robinson \& Walter, 2009; Nakata, 2007; Rigney, 2001).

In my study, my circumstances were that I had existing relationships with some school sites, which I believe impacted on how my conditions of entry were constructed in those cases. In others, the opportunity to discuss conditions of entry were blocked entirely without any prospect of negotiating or mediating with gatekeepers. The clear lack of neutrality in the role of gatekeepers in institutions such as schools with would-be Indigenist researchers such as myself, presents serious issues in being able to authentically consult and collaborate with Indigenous participants in school sites, as espoused by Indigenous research ethical guidelines and Indigenist theorists. With gatekeepers holding the authority to grant entry or place conditions upon entry, there is very little prospect for Indigenist researchers to define our own research problems and negotiate directly with participants about further defining the problem and the focus of the study. This is problematic because standpoint and how we perceive, observe and construct research problems, matters.

The abundance of research on Indigenous education has not resulted in any significant discoveries or improvements, and this research has been 
undertaken by mostly non-Indigenous researchers (Harrison, 2007). Counter stories are imperative, not just because it is essential to hear from those who hold the experiential knowledge; but also because experiential knowledge provides a different lens with which to construct and analyse the problem. Through the lived experiences of Indigenous peoples, the topic of race and racism often surfaces. Indigenous researchers often write of the importance of including the issue of race in relation to Indigenous scholarship (Carlson, 2011; Sarra, 2011). Critical race scholars also argue that specific examination of the role of race and racism, including schools and education systems, is vital in examining racial educational inequality that persists in many Western countries (Ladson-Billings, 1998; Ladson-Billings \& Tate, 2006; Solórzano \& Yosso, 2002; Zamudio, Russell, Rios, \& Bridgeman, 2011). The avoidance and conflated understanding of the topic of race and racism by educators is well documented (Aveling, 2002, 2007; Blackmore, 2010; Moreton-Robinson, Singh, Kolopenuk, Robinson, \& Walter, 2012). Bodkin-Andrews and Carlson (2014) evaluate that without insider or counter experiences outside of the realm of Western epistemologies framing inquiries on important topics such as race and racism, "it becomes apparent that the insidious effects of epistemological racism still plagues the Indigenous Australian educational research agenda" (p. 3).

Gatekeepers hold far more authority for Indigenous peoples than simply allowing or blocking research from being undertaken; they hold the authority to control how knowledge about us is produced and re-produced. Although the Australian Government promotes their resounding support for improving educational outcomes for Indigenous people, the lack of authority to control something as significant as knowledge production about us seems to be in complete contradiction to current education policy. As BodkinAndrews and Carlson (2014) point out, not only is it exclusionary by virtue of the dominance of Western knowledge systems, it also reproduces a different form of racism.

The role of ethics and gatekeeping are closely related. As mentioned earlier in this section, Heath et al. (2007) analysed the role of gatekeepers in gaining informed consent with children and vulnerable groups. Heath et al. critiqued positionality of potential participants, researchers and gatekeepers 
as problematic in undertaking the process of informed consent in research contexts. In their example, Heath et al. discussed the barrier of age structures within institutions in giving children the ability and agency to make decisions about their participation. Although the role of the gatekeeper is to protect children from being exploited thus bound with ethical research practices, it also has a paradoxical function of impeding a child's ability to be included in the decisions about them, that impinge on them.

Indigenous peoples in Australia are also categorised as a vulnerable group in research (Australian Institute of Aboriginal and Torres Strait Islander Studies, 2012; National Health \& Medical Research Council, 2003). The status of vulnerability is due to the extensive objectification, exploitation, exclusion and subjugation of us in research that have been conducted in the not-too-distant past (some would argue there are still examples of such studies) (Martin, 2012; Moreton-Robinson \& Walter, 2009; Rigney, 2006). While Heath et al. (2007) analyse age structures within institutions to consider how gatekeeping impacts on the rights and agency of children, intersections of age structures and race are important sites of causation to analyse when discussing ethics and Indigenist research.

Indigenous people have been racially constructed in Australia as inferior, other and less worthy since invasion (Moreton-Robinson, 2009). The social racialisation of Indigenous peoples and non-Indigenous peoples in Australia is then also connected with how gatekeepers undertake their ethical roles in 'protecting' us from further research that has not served our interests or accurately represented our lived experiences. Furthermore, protectionist discourse (that we need protecting from ourselves and others) must impinge on a gatekeeper's ability to reconcile the social construction of us needing protection with the 'vulnerable' Indigenous person now asking for access to their own group to undertake research. Social racialisation of White Australia implicitly tells a gatekeeper that they have more knowledge or authority to make decisions on behalf of the vulnerable Indigenous group that they are protecting. The invisible authority that is granted to make such decisions is constituted by virtue of how Whiteness discursively operates to keep Indigenous peoples subordinate thus maintaining the power and privileges that continue to benefit white people and systems (Blackmore, 2010; Moreton-Robinson, 2003). Recognition of this very real obstacle for Indigenous researchers who want to undertake research in institutionalised 
contexts such as schools is necessary to progress discussions about ethics and Indigenous research.

Wanat (2008) explains that gatekeepers in schools will often avoid topics that are sensitive. The topic of Indigenous peoples and affairs, in addition to racism could not only be categorised as being sensitive, but fraught with historically situated denial, untruths and assumptions. The difficulty in getting (non-Indigenous and White people in the main) to engage critically in Indigenous studies in education undergraduate programs has been written about by scholars such as Aveling (2002, 2006), Hart et al. (2012) and Phillips (2011). All of these authors stress the importance of compulsory Indigenous Studies in teacher education programs, yet acknowledge that students often enter the learning space with hostility, resistance and limited existing knowledge to draw on. The fear and resistance that exists in compulsory Indigenous education coursework is not limited to pre-service teachers.

Ma Rhea (2013) reported that there is widespread fear and concern amongst teachers nationwide in the recent policy changes that included mandatory teacher standards that require teachers to now know about Indigenous peoples, histories and cultures as well as to know how to effectively teach Indigenous students. Evidence is mounting that we currently have an education workforce who self-identify their deficiencies and lack of understanding about Indigenous peoples and issues. In relation to gatekeeping Indigenist research, the paramount question is, how are gatekeepers who likely have limited knowledge themselves about Indigenous peoples, cultures, communities and issues, able to make sound decisions about whether research (by Indigenous or non-Indigenous researchers) is appropriate and in the interests of their Indigenous students or staff? Moreover, researchers with specific experience and training in conducting Indigenist research are extremely limited. Leaving decisions to gatekeepers that have not engaged in any research training or have very limited understanding about the context of Indigenous research is not serving the interests of Indigenous peoples. 


\section{Conclusion}

In sum, I have used some of my reflections from my doctoral study to illustrate the need for expansion on current literature for Indigenous researchers who want to undertake education research. I briefly outlined two key documents, the NHMRC and AIATSIS ethics guidelines for conducting Indigenous research. My reflections and understanding of the ethics guidelines for undertaking Indigenous research revealed another gap in the literature whereby Indigenist researchers are using frameworks that are catering for a mostly non-Indigenous audience. In using my research reflections, I was able to critically analyse my experiences through examining literature on institutionalisation of education, gatekeeping and Indigenist research. Although I identified more problems than solutions, identifying where the issues are ended up being a critical aspect of this study in recognising the nexus between theory and practice in Indigenist research.

Indigenous researchers identify research problems and conceptualise research based on our diverse experiences as Indigenous peoples. I propose that Indigenous researchers need to continue to contribute to methodological and theoretical research literature through writing about our lived experiences as Indigenous researchers, providing insights for opportunities to overcome challenges and bring forth aspirations that exist in our communities. Finally, we need to create a body of scholarship that speaks to Indigenous researchers and provides practical solutions for the real issues that exist. The current Indigenous education focus on "Closing the Gap" must include the contribution that Indigenous researchers can make in solving complex issues created by colonialism.

\section{Notes}

${ }^{1}$ Terra Nullius - land belonging to nobody

\section{Acknoledgment}

This PhD is supervised by A/Prof Jo Lampert, A/Prof Grace Sarra and Aunty Denise Proud. Thanks and acknowledgement goes to my supervision team for their feedback on my research and their ongoing mentoring and guidance. 
292 Shay - Aboriginal Education Research

\section{References}

ACARA. (2015). Australia Curriculum. Retrieved from http://www.australiancurriculum.edu.au/

AITSL. (2013). Australian Professional Standards for Teachers. Retrieved from http://www.aitsl.edu.au/australian-professional-standards-forteachers/standards/list

Australian Government. (2012). Review of Higher Education Access and Outcomes for Aboriginal and Torres Strait Islander People Final Report. Retrieved from Retrieved from http://docs.education.gov.au/system/files/doc/other/heaccessandoutcomes foraboriginalandtorresstraitislanderfinalreport.pdf

Australian Government. (2014). Aboriginal and Torres Strait Islander Workforce Analysis More Aboriginal and Torres Strait Islander Teachers Initiative. Retrieved from http://matsiti.edu.au/wpcontent/uploads/2014/09/MATSITI-Data-Analysis-Report-2014.pdf

Australian Institute of Aboriginal and Torres Strait Islander Studies. (2012).

Guidelines for Ethical Research in Australian Indigenous Studies.

Retrieved from http://www.aiatsis.gov.au/_files/research/GERAIS.pdf Aveling, N. (2002). Student Teachers' Resistance to Exploring Racism:

Reflections on 'doing' border pedagogy. Asia-Pacific Journal of Teacher Education, 30(2), 119-130. doi:10.1080/13598660220135630

Aveling, N. (2006). 'Hacking at our very roots': rearticulating White racial identity within the context of teacher education. Race Ethnicity and Education, 9(3), 261-274. doi:10.1080/13613320600807576 Aveling, N. (2007). Anti-racism in Schools: A question of leadership?

Discourse: Studies in the Cultural Politics of Education, 28(1), 69-85. doi:10.1080/01596300601073630

Barley, S. R., \& Tolbert, P. S. (1997). Institutionalization and Structuration: Studying the Links between Action and Institution. Organization Studies, 18(1), 93-117. doi:10.1177/017084069701800106

Berg, G. (2007). From structural dilemmas to institutional imperatives: a descriptive theory of the school as an institution and of school organizations. Journal of Curriculum Studies, 39(5), 577-596. doi:10.1080/00220270600880994 
Bessarab, D., \& Ng'andu, B. (2010). Yarning about Yarning as a Legitimate Method in Indigenous Research. International Journal of Critical Indigenous Studies, 3(1), 37-50. Retrieved from

http://www.isrn.qut.edu.au/pdf/ijcis/v3n1_2010/Final_Bessarab_Bridget_ IJCIS.pdf

Blackmore, J. (2010). 'The Other Within': race/gender disruptions to the professional learning of white educational leaders. International Journal of Leadership in Education, 13(1), 45-61.

doi:10.1080/13603120903242931

Bodkin-Andrews, G., \& Carlson, B. (2014). The legacy of racism and Indigenous Australian identity within education. Race Ethnicity and Education, 1-24. doi:10.1080/13613324.2014.969224

Bold, C. (2012). Using Narrative in Research. Using Narrative in Research. London: SAGE Publications Ltd.

Carlson, B. (2011). The politics of identity: who counts as aboriginal today? (PhD), UNSW. Retrieved from

http://www.unsworks.unsw.edu.au/primo_library/libweb/action/dlDispla y.do?vid=UNSWORKS\&docId=unsworks_10196

Foley, D. (2003). Indigenous Epistemology and Indigenous Standpoint Theory. Social Alternatives, 22(1), 44-52.

Harrison, N. (2007). Where Do We Look Now?: The Future of Research in Indigenous Australian Education. Australian Journal of Indigenous Education, 36, 1-5.

Hart, V., Whatman, S., McLaughlin, J., \& Sharma-Brymer, V. (2012). Preservice teachers' pedagogical relationships and experiences of embedding Indigenous Australian knowledge in teaching practicum. Compare: A Journal of Comparative and International Education, 42(5), 703-723. doi:10.1080/03057925.2012.706480

Heath, S., Charles, V., Crow, G., \& Wiles, R. (2007). Informed Consent, Gatekeepers and Go-Betweens: Negotiating Consent in Child- and Youth-Orientated Institutions. British Educational Research Journal, 33(3), 403-417.

Jakobi, A. P. (2011). Political Parties and the Institutionalization of Education: A Comparative Analysis of Party Manifestos. Comparative Education Review, 55(2), 189-209. doi:10.1086/657931 
Ladson-Billings, G. (1998). Just what is critical race theory and what's it doing in a nice field like education? International Journal of Qualitative Studies in Education, 11(1), 7-24. doi:10.1080/095183998236863

Ladson Billings, G., \& Tate, W. (2006). Toward a critical race theory in education. In A. Dixson \& C. Rousseau (Eds.), Critical Race Theory in Education All god's children got a song (pp. 11-31). USA: Routledge. Lampert, J., \& Burnett, B. (2012). Retention and graduation of Aboriginal and Torres Strait Islander students in initial teacher education: a review of the literature. Paper presented at the Australian Teacher Education Association Annual Conference, Stamford Grand Hotel, Adelaide, SA. retrieved, November, 2014 from http://eprints.qut.edu.au/58067/

Ma Rhea, Z. (2013). Indigenous education and teacher professional development: the Australian professional standards for teacheres in Australia. Retrieved fom http://www.ieu.asn.au/media/71851/zane_ma_rhea1.pdf

Martin, K. (2003). Ways of knowing, being and doing: A theoretical framework and methods for indigenous and indigenist research. Journal of Australian Studies, 27(76), 203-214.

Martin, K. (2012). Please knock before you enter Aboriginal regulations of Outsiders and the implications for researchers. Teneriffe: Post Pressed.

Merriam-Webster. (2016). Online Dictionary. Retrieved from http://www.merriam-webster.com/dictionary/gatekeeper

Moran, A. (2005). White Australia, Settler Nationalism and Aboriginal Assimilation. Australian Journal of Politics \& History, 51(2), 168-193. doi:10.1111/j.1467-8497.2005.00369.x

Moreton-Robinson, A. (2003). Researching Whiteness: Some Reflections from an Indigenous Woman's Standpoint. Hecate, 29(2), 72-85.

Moreton-Robinson, A. (2009). imagining the good indigenous citizen: Race War and the Pathology of Patriarchal White Sovereignty. Cultural Studies Review, 15(2), 61-79.

Moreton-Robinson, A., Singh, D., Kolopenuk, J., Robinson, A., \& Walter, M. (2012). "Learning the Lessons? Pre-Service Teacher Preparation for Teaching Aboriginal and Torres Strait Islander Students" A Report prepared for the Division of Indigenous Education and Training Futures - 
Queensland Department of Education, Training and Employment, Indigenous Studies. Retrieved from http://www.aitsl.edu.au/docs/defaultsource/aitsl-research/insights/re00044_learning_the_lessons-_preservice_teacher_preparation_for_teaching_aboriginal_and_torres_strait_i slander_students_qut_oct_2012.pdf?sfvrsn=6

Moreton-Robinson, A., \& Walter, M. (2009). Indigenous methodologies in social research. Social research methods, 1-18.

Murgatroyd, P., Karimi, L., Robinson, P., \& Rada, J. (2015). On the use/misuse of health research gatekeeping powers in Australia: An underconsidered problem? Asia Pacific Journal of Health Management, 10(3), SI63-SI69.

Nakata, M. (2007). The Cultural Interface. Australian Journal of Indigenous Education, 36(Supplementary), 7-14. Retrieved from

http://search.informit.com.au.ezp01.library.qut.edu.au/documentSummar y; $\mathrm{dn}=903053619367156 ;$ res=IELIND

National Health \& Medical Research Council. (2003). Values and Ethics: Guidelines for Ethical Conduct in Aboriginal and Torres Strait Islander Health Research. Retrieved from

https://www.nhmrc.gov.au/_files_nhmrc/publications/attachments/e52.pd f

Phillips, J. (2011). Resisting contradictions : non-Indigenous pre-service teacher responses to critical Indigenous studies. Queensland University of Technology, Brisbane. Retrieved from http://eprints.qut.edu.au/46071/

Phillips, J., \& Lampert, J. (2012). Introductory Indigenous Studies in Education (2nd ed.). Frenchs Forest NSW: Pearson.

Price, K. (2012). A brief history of Aboriginal and Torres Strait Islander education in Australia Aboriginal and Torres Strait Islander education : an introduction for the teaching profession. New York: Cambridge University Press.

Ramirez, F. O., \& Boli, J. (1987). The Political Construction of Mass Schooling: European Origins and Worldwide Institutionalization. Sociology of Education, 60(1), 2-17.

Rigney, L. (2001). A first perspective of Indigenous Australian participation in science : framing Indigenous research towards Indigenous Australian intellectual sovereignty. Kaurna Higher Education Journal(7), 1-13. 
Rigney, L. (2006). Indigenist research and Aboriginal Australia. In N. Goduka \& J. Kunnie (Eds.), Indigenous people's wisdoms and power: Affirming our knowledges through narrative (pp. 32-50). London:

Ashgate Publishing.

Sanghera, G. S., \& Thapar-Björkert, S. (2008). Methodological dilemmas: gatekeepers and positionality in Bradford. Ethnic and Racial Studies, 31(3), 543-562. doi:10.1080/01419870701491952

Sarra, C. (2011). Strong and Smart - Towards a Pedagogy for Emancipation: Education for first peoples. Oxon: Routledge

Shay, M. (2015). The perceptions that shape us: strengthening Indigenous young people's cultural identity. In T. Ferfolja, Jones-Diaz, C. \& Ullman, J. (Ed.), Understanding sociological theory and pedagogical practices (pp. 93-105). Melbourne: Cambridge University Press.

Shoemaker, P. J., \& Vos, T. P. (2009). Gatekeeping theory (Vol. 1). GB: Routledge Ltd.

Solórzano, D. G., \& Yosso, T. J. (2002). Critical Race Methodology:

Counter-Storytelling as an Analytical Framework for Education

Research. Qualitative Inquiry, 8(1), 23-44.

doi:10.1177/107780040200800103

Wanat, C. L. (2008). Getting Past the Gatekeepers: Differences Between Access and Cooperation in Public School Research. Field Methods, 20(2), 191-208. doi:10.1177/1525822X07313811

Zamudio, M., Russell, C., Rios, F., \& Bridgeman, J. L. (2011). Critical Race Theory Matters: Education and Ideology Retrieved from http://QUT.eblib.com.au/patron/FullRecord.aspx?p=592906

Marnee Shay: lecturer in the School of Cultural and Professional Learning, Faculty of Education, Queensland University of Technology

Contact Address: ms.shay@qut.edu.au 